\title{
Carbon Capture and Storage in Geological Formation; Its Legal, Regulatory Imperatives and Opportunities in India
}

\author{
Krunal Kalbende \\ Dept of Geology and Geophysics, IIT Kharagpur, Kharagpur, India
}

Email address:

krunal.iitkgp@gmail.com

\section{To cite this article:}

Krunal Kalbende. Carbon Capture and Storage in Geological Formation; Its Legal, Regulatory Imperatives and Opportunities in India. International Journal of Environmental Monitoring and Analysis. Vol. 3, No. 3, 2015, pp. 198-204. doi: 10.11648/j.ijema.20150303.22

\begin{abstract}
The Carbon Capture and Storage Technology (CCS) provides a veritable platform to bridge the gap between the seemingly irreconcilable twin global challenges of ensuring a secure, reliable and diversified energy supply and mitigating climate change by reducing atmospheric emissions of carbon dioxide. Making its proper regulatory policy and making it flexible for the government and private company by law to regulate, also exploring the opportunity in this sector is the main aim of this paper. India's total annual emissions were $1725 \mathrm{Mt} \mathrm{CO}_{2}$ in 2011 , which comprises of $6 \%$ of total global emission [1]. It is very important to control the greenhouse gas emission for the environment protection. This paper discusses the various regulatory policy and technology adopted by some of the countries for successful using CCS technology. The brief geology of sedimentary basins in India is studied, ranging from the category I to category IV and deep-water and potential for mature technology in CCS is reviewed. Areas not suitable for $\mathrm{CO}_{2}$ storage using presently mature technologies were overviewed. CCS and Clean development mechanism was advised for India, considering the various aspects from research and development, project appraisal, approval and validation, implementation, monitoring and verification, carbon credit issued, cap and trade system and its storage potential. The opportunities in oil and gas operations, power sector, and transport sector were discussed briefly.
\end{abstract}

Keywords: Carbon Credit Issued, Cap and Trade System, Carbon Capture and Storage Technology, Greenhouse Gas

\section{Introduction}

The Introduction of $\mathrm{CO}_{2}$ emission into the atmosphere is largely responsible for the climate change challenge facing the universe today. This gas is usually emitted through the burning of fossil fuel (oil, gas and coal) in domestic and industrial process. A carbon footprint is historically defined as "the total sets of greenhouse gas emissions caused by an organization, event, product or person [2]." The total carbon footprint cannot be calculated because of the large amount of data required and the fact that carbon dioxide can be produced by natural occurrences. It is for this reason that Wright, Kemp, and Williams, writing in the journal Carbon Management, have suggested a more practicable way to measure the total amount of carbon dioxide $\left(\mathrm{CO}_{2}\right)$ and methane $(\mathrm{CH} 4)$ emissions of a defined population, system or activity, considering all relevant sources, sinks and storage within the spatial and temporal boundary of the population, system or activity of interest. Calculated as equivalent $\left(\mathrm{CO}_{2} \mathrm{e}\right)$ using the relevant 100-year global warming potential (GWP100). This paper give us the potential of CCS and
Clean development mechanism which can be developed for India, considering the various aspects from research and development, project appraisal, approval and validation, implementation, monitoring and verification, carbon credit issued, cap and trade system and its storage potential. The opportunities in oil and gas operations, power sector and transport sector were discussed briefly. This paper also examines the concept of CCS as well as its process stages. It also highlights some major CCS projects and their various degrees of legal responsibility and process associated with it.

\section{The International Energy Agency}

It is a Paris-based autonomous intergovernmental organization established in the framework of the Organization for Economic Co-operation and Development (OECD) in 1974 in the wake of the 1973 oil crisis. The IEA acts as a policy adviser to its member states, but also works with non-member countries, especially China, India, and Russia. The Agency's mandate has broadened to focus on the "3Es" of effectual energy policy: energy security, economic development, and environmental protection. IEA member 
countries are required to maintain total oil stock levels equivalent to at least 90 days of the previous year's net imports.

\section{Carbon Capture and Storage}

The Carbon Capture and Storage Technology provides a veritable platform to bridge the gap between the seemingly irreconcilable twin global challenges of ensuring a secure, reliable and diversified energy supply and mitigating climate change by reducing atmospheric emissions of $\mathrm{CO}_{2}$. The introduction of carbon dioxide $\left(\mathrm{CO}_{2}\right)$ emissions into the atmosphere is largely responsible for the climate change challenge facing the universe today. This gas is usually emitted through the burning of fossil fuel (oil, gas and coal) in domestic and industrial processes. It is trite fact that the atmospheric concentrations of $\mathrm{CO}_{2}$ and other greenhouse gases would have to be considerably reduced or at least stabilized in order to save the environment from the deleterious consequences of global warming. The introduction of carbon dioxide $\left(\mathrm{CO}_{2}\right)$ emissions into the atmosphere is largely responsible for the climate change challenge facing the universe today. This gas is usually emitted through the burning of fossil fuel (oil, gas and coal) in domestic and industrial processes [3]. It is trite fact that the atmospheric concentrations of $\mathrm{CO}_{2}$ and other greenhouse gases would have to be considerably reduced or at least stabilized in order to save the environment from the deleterious consequences of global warming. Many ways have been suggested some of suggest to shift to sustainable energy from renewable sources like wind, solar, hydro, biomass, geothermal. We can make Energy Efficiency by burning less coal, oil or gas. It is very important for adaptation of technology that would allow the continuous use of fossil fuels whilst decreasing the amount of $\mathrm{CO}_{2}$ that is being released into the atmosphere.

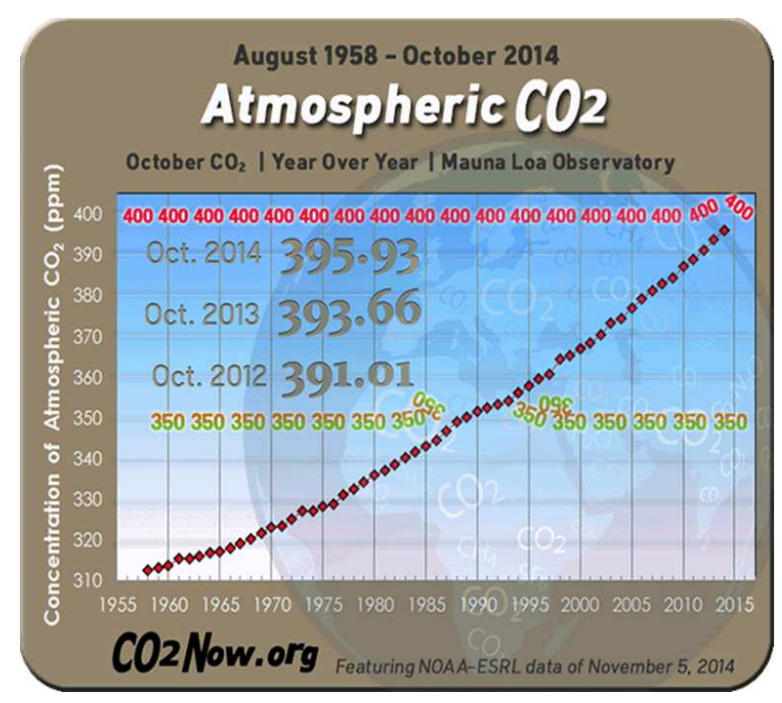

Fig 1. Concentration of $\mathrm{CO} 2$ in the atmosphere. (Source $\mathrm{CO}_{2}$ Now.org).

The 2013 average annual concentration of $\mathrm{CO}_{2}$ in the atmosphere (Mauna Loa Observatory) is 396.48 parts per million (ppm) [4]. The 2012 average is $393.82 \mathrm{ppm}$. For the past decade (2004-2013) the average annual increase is 2.1 ppm per year. The average for the prior decade (1994-2003) is 1.9 ppm per year. Annual data for 2012 was first posted January 9, 2014, by NOAA-ESRL in the United States. Since the 1958 start of precision $\mathrm{CO}_{2}$ measurements in the atmosphere, the annual mean concentration of $\mathrm{CO}_{2}$ has only increased from one year to the next. The $\mathrm{CO}_{2}$ data in Fig 1 provide a simple view of the annual trend. Upper safety limit for atmospheric $\mathrm{CO}_{2}$ is 350 parts per million [4]. For the past ten years, the average annual rate of increase is 2.07 parts per million (ppm). This rate of increase is more than double the increase in the 1960s.

\section{How CCS Works}

When fossil fuels such as coal, natural gas or oil are burned or processed to produce energy or other petroleum based products, carbon dioxide $\left(\mathrm{CO}_{2}\right)$ and other pollutants are generated as by-products. Presently, these emissions are released into the atmosphere in the form of GHGs [5]. CCS is a process through which $\mathrm{CO}_{2}$ can be diverted from the atmosphere by capture and storage. "CCS is a waste management strategy for carbon dioxide. It does not reduce the production of $\mathrm{CO}_{2}$, but it provides a depository to keep it from harming the environment". The CCS process has three distinct elements. First, the emitted $\mathrm{CO}_{2}$ is captured from industrial utility and compressed either in supercritical form or sub-cooled liquid form for underground storage. The captured $\mathrm{CO}_{2}$ is transported via pipeline or ships to the storage site and injected into deep saline aquifires, depleted oil and gas fields or unmineable coal seams or through an industrial process that permanently fixates the $\mathrm{CO}_{2}$ into inorganic carbonates using chemical reactions or industrial use of $\mathrm{CO}_{2}$ for production of carbon compounds or chemicals.

\subsection{Capture and Compression}

The most promising $\mathrm{CO}_{2}$ capture technologies are post-combustion and pre-combustion processes. In the more conventional post-combustion approach, $\mathrm{CO}_{2}$ is captured from the gases emitted from burning coal or natural gas to produce energy. The pre-combustion method is used when hydrogen and $\mathrm{CO}_{2}$ are stripped from natural gas. Hydrogen is used either to produce electricity (with only water as a byproduct) or in other industrial processes such as bitumen refining. The $\mathrm{CO}_{2}$ that is currently emitted into the atmosphere through both the pre and post combustion processes could be captured and made ready (compressed) for transportation to a suitable storage site. A third capture technique is oxyfuel combustion. Similar to post-combustion, the fuel is burned in pure oxygen which results in a much purer $\mathrm{CO}_{2}$ stream than when the fuel is burned in air [6].

\subsection{Transportation}

Once the $\mathrm{CO}_{2}$ is captured and compressed, it can be 
transported to storage sites either through pipelines or mobile transport facilities (trains, ships or trucks). Again, given the amount of $\mathrm{CO}_{2}$ that would be required to transport for storage, using pipeline facilities is the most feasible transportation option. Shipping of $\mathrm{CO}_{2}$ would be similar to shipping liquefied natural gas.

\subsection{Storage}

The final stage in the CCS process is long term storage of $\mathrm{CO}_{2}$. To achieve successful storage in terms of mitigating the damaging environmental effects of GHG accumulations in the atmosphere, such storage must be relatively permanent. Permanence means that the $\mathrm{CO}_{2}$ must not leak back into the atmosphere at any significant rate for hundreds of years. To achieve this kind of permanence of storage, injection of $\mathrm{CO}_{2}$ must take place at depths in excess of 800 meters so that geological cap rock and other geochemical trapping mechanisms can prevent the gas from migrating back to the surface. These kind of geological formations are found both on and offshore in various locations around the world. Deep saline aquifers and depleted oil and gas reservoirs are generally considered the most suitable geological formations for long-term $\mathrm{CO}_{2}$ storage. A possible storage location for $\mathrm{CO}_{2}$ is at the bottom of deep sea beds. $\mathrm{CO}_{2}$ can either be injected into the water column for dissolution or injected through pipelines to the deep sea bed [7]. The $\mathrm{CO}_{2}$ would then remain at the bottom of the sea bed in the form of a "lake" since liquid $\mathrm{CO}_{2}$ is denser than sea water. Finally, injection of $\mathrm{CO}_{2}$ into coal bed seams to recover methane is in the early stages of research and development.

\section{Case Study on CCS}

Over the years, $\mathrm{CO}_{2}$ injection activities have been undertaken in the oil and gas industry. There are around 70 $\mathrm{CO}_{2}$ Enhanced Oil Recovery (EOR) sites globally carrying out $\mathrm{CO}_{2}$ injection, all operated by major and independent oil companies. The majority is in North America where approximately 40 million metric tonnes of $\mathrm{CO}_{2}$ are injected annually. Others are planned or already operating in Australia the United Arab Emirates, North America, China and parts of Europe [8]. However, on a large commercial scale, the development of CCS projects is still emerging.

\subsection{Sleipner West, off the Coast of Norway}

This project began injecting $\mathrm{CO}_{2}$ in 1996 and is being managed by Statoil. $\mathrm{CO}_{2}$ is stored from industrial sources into the subsurface beneath the North Sea in Norway. It is the first commercial scale CCS project in the world, storing up to 7.5 million tonnes of $\mathrm{CO}_{2}$ to date and with a potential of injecting 20 million tonnes of $\mathrm{CO}_{2}$. Specific regulatory issues that were addressed in the Sleipner project include the grant of access and property rights by the Norwegian government to Statoil, the main operator and its operational partners [9]. International Property (IP) rights on the results of the Sleipner project was vested on the project partners [9]. A monitoring and verification programmer was also set for the project to include developing and testing methods for baseline evaluation, developing new tools for monitoring storage and possible leakage, developing new tools to predict long-term behavior and risks, developing a generic risk assessment methodology for different sites and timeframes, and developing guidelines for best practice.

\subsection{Gorgon, Australia}

This is a private sector CCS project with Chevron as the lead partner in the Gorgon Joint Venture Group, which also includes ExxonMobil and Royal Dutch Shell. The project is part of a large natural gas processing facility that is planned to be built. Once the injections begin, it will be the largest-scale $\mathrm{CO}_{2}$ storage project in the world, with an intended injection rate of up to 10,000 tonnes of $\mathrm{CO}_{2}$ per day. The project aims to inject approximately 2.7 million tonnes per year over a potential project lifetime of 40 years. It has a total injection potential of 120 million tonnes.

Under the Gorgon project, stored $\mathrm{CO}_{2}$ is defined as a byproduct of gas processing operations under the Barrow Island Act of 2003 [10]. Ownership of the injected $\mathrm{CO}_{2}$ during project operation belongs to the project developers. This terminates at the point of storage/disposal, though liability may still subsist. However, this does not imply that government takes on ownership at this time, as there are no such provisions in the Barrow Islands Act [10]. The Gorgon project partners also provide for a range of monitoring and verification programmes based on current available technologies, but anticipate that monitoring activities will likely evolve over the duration of the project.

\section{Sedimentary Basins in India}

India has 26 sedimentary basins covering an area of 3.14 million square kilometers. The sedimentary basins of India, on land and offshore up to the $200 \mathrm{~m}$ isobath, have an aerial extent of about 1.79 million sq. $\mathrm{km}$. In the deepwater beyond the $200 \mathrm{~m}$ isobaths, the sedimentary area has been estimated to be about 1.35 million sq. $\mathrm{km}$. Thus, the total works out to 3.14 million sq. km [11]. Broadly Indian sedimentary basins have been divided into four categories based on their degree of prospectively as presently known. The categorization based on the prospectively of the basin as presently known is as under (Table 1).

Table 1. Categories of Indian sedimentary basins.

\begin{tabular}{llll}
\hline Types of basins & Area (sq.Km) & Hydrocarbon Prospectivity & Basin/Regions \\
\hline $\begin{array}{l}\text { Category I } \\
\text { ( } 7 \text { Basins) }\end{array}$ & 518500 & Establshed commercial production & Cambay, Assam shelf, Mumbai offshore, Krishna godavari, \\
& & & Couvery, Assam Arakan Fold Belt and Rajasthan \\
\hline
\end{tabular}




\begin{tabular}{lcll}
\hline Types of basins & Area (sq.Km) & Hydrocarbon Prospectivity & Basin/Regions \\
\hline $\begin{array}{l}\text { Category II } \\
\text { (3 Basins) }\end{array}$ & 164000 & $\begin{array}{l}\text { Known accumulation of hydrocarbon but no } \\
\text { commercial production as yet }\end{array}$ & Kutch, Mahanadi-NEC and Andaman-Nicobar \\
$\begin{array}{l}\text { Category III } \\
\text { (6 Basins) }\end{array}$ & 641000 & $\begin{array}{l}\text { Indicated Hydrocarbon shows that are } \\
\text { considered geologically Prospective }\end{array}$ & $\begin{array}{l}\text { Himalayan foreland, Ganga, Vindhaya, saurashtra, } \\
\text { keral-konkan, lakshadweep and Bengal }\end{array}$ \\
$\begin{array}{l}\text { Category I } \\
(10 \text { Basins) }\end{array}$ & 461200 & $\begin{array}{l}\text { Uncertain potential which may be prospective } \\
\text { by analogy with similar basin in the world }\end{array}$ & $\begin{array}{l}\text { Karewa, Spiti-Zanskar, Satpura-South Rewa-Damodar, } \\
\text { Narmada, Deccan Syneclise, Bhima-Kaladgi, Cuddapah, } \\
\text { Pranhita-Godavari, Bastar, Chhattisgarh. }\end{array}$ \\
$\begin{array}{l}\text { Deepwater } \\
\text { Total }\end{array}$ & 1350000 & East and West coast from 400m water depth to EEZ \\
\hline
\end{tabular}

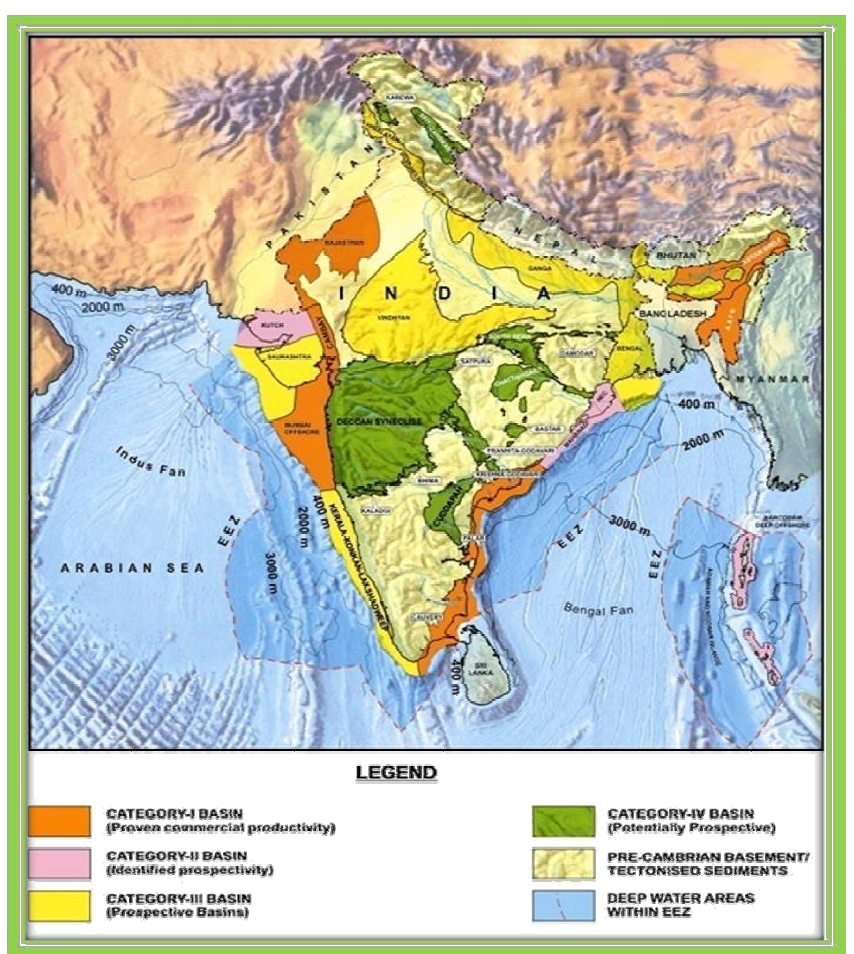

Fig 2. Showing the geographical location of sedimentary basin with categories.

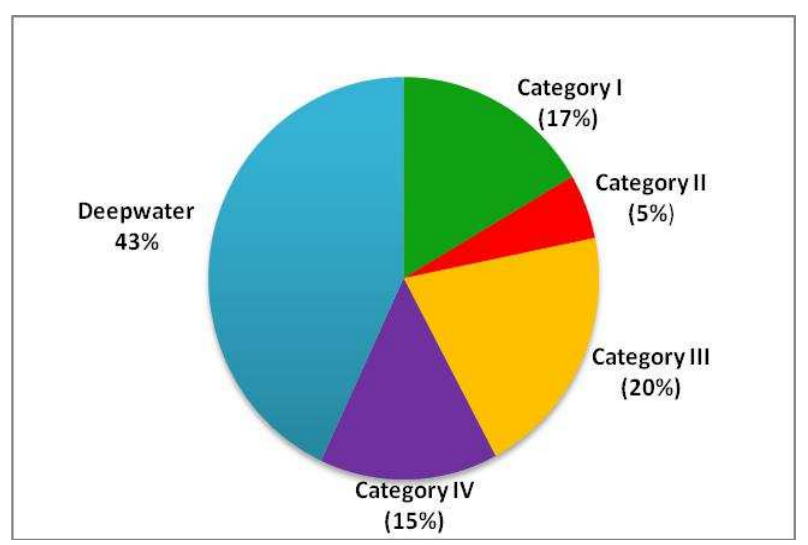

Fig 3. The distribution of total Indian sedimentary area of 3.14 million square kilometre under different categories and deepwater.

Crude oil \& natural gas production in the country is from 7 basins under category-I and Deepwater areas. In category-II basins, hydrocarbon discoveries have been made but commercial production is yet to commence. The distribution of total Indian sedimentary area of 3.14 million square kilometer under different categories and deep-water is presented as shown in Fig 2 and Fig 3.

\section{Geological Storage Potential for $\mathrm{CO}_{2}$}

Estimates for the geological storage potential in India are in the range of 500-1000 Gt of $\mathrm{CO}_{2}$, including on-shore and off-shore deep saline formations (300-400 Gt), basalt formation traps (200-400 Gt), unmineable coal seams (5Gt), and depleted oil and gas reservoirs (5-10 Gt)[7]. Analysis of oil and gas fields around India shows that relatively few fields have the potential to store the lifetime emissions from even a medium-sized coal-fired power plant. However, recently discovered offshore fields could provide opportunities in the future. The potential for $\mathrm{CO}_{2}$-EOR needs to be further analysed on a basin-by-basin basis; it is not possible to develop a suitable estimate today [12] Deccan Volcanic Province, the basalt rock region in the northwest of India, is one of the largest potential areas for $\mathrm{CO}_{2}$ storage. The total area considered is $500000 \mathrm{~km}^{2}$ and corresponds to a volume of 550,000 km3 with 13-20 different flow units. 3 It reaches 2000 meters on the western flank. Storage volumes are in the range of $300 \mathrm{Gt}$ of $\mathrm{CO}_{2}$ [13].

Thick sedimentary rocks (up to 4000 metres) exist below the basalt trap. In order to model the long-term fate of $\mathrm{CO}_{2}$ injection in such mineral systems, geo-chemical and geo-mechanical modelling of interaction between fluids and rocks is required. There is considerable potential for $\mathrm{CO}_{2}$ storage in deep saline aquifers, particularly at the coast and on the margins of the Indian peninsula, particularly in Gujarat and Rajasthan. Fig 4 shows this and also demonstrated aquifer storage this and also demonstrated aquifer storage potential in the areas surrounding Assam, although these reservoirs are $750-1000 \mathrm{~km}$ from five large point sources, each with annual emissions greater than $5 \mathrm{Mt}$. Therefore, $\mathrm{CO}_{2}$ storage may prove costly due to transportation expenses. The Indo-Gangetic foreland is an important potential storage site [14]. The Ganga Eocene-Miocene Murree-Siwalik formations are fluvial sandstones that have good storage potential as deep saline formations. Their high salinity and depth prevents from an economical surface use. The Ganga area has a basin area of $186,000 \mathrm{~km} 2$, with a large thickness of caprock composed of 
low permeability clay and siltstone [15]. The proximity of the sources to the potential storage site makes it a good candidate for a pilot project.

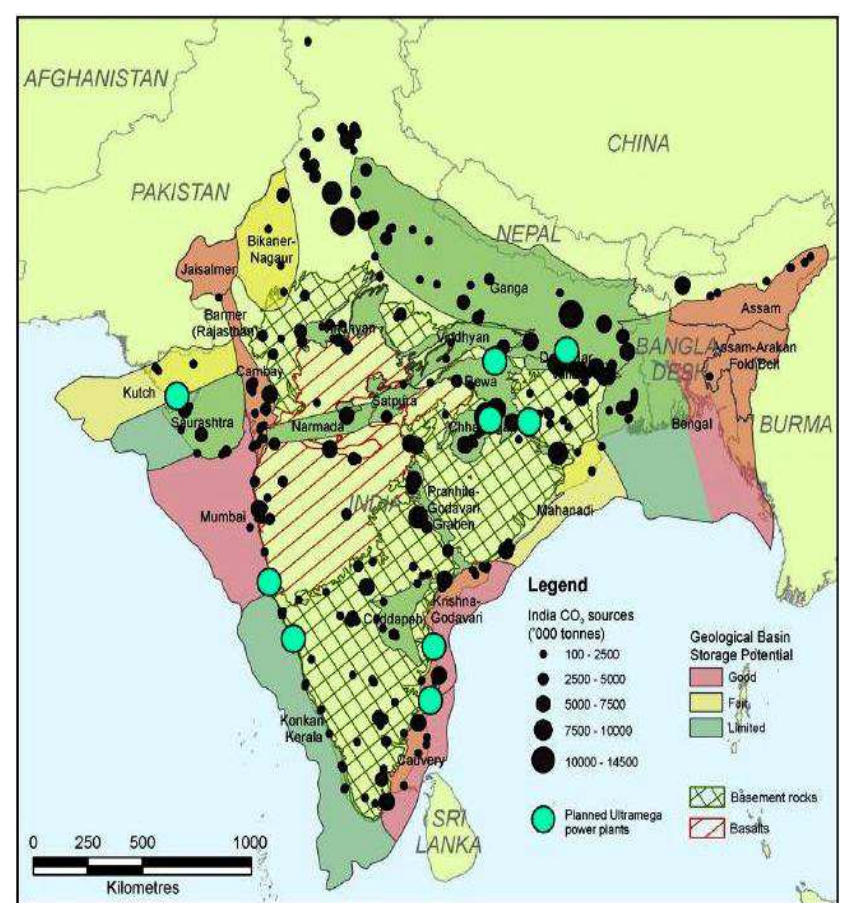

Fig 4. Present and future sources of $\mathrm{CO}_{2}$ and geological basins with storage potential (Source:A regional assessment of the potential for $\mathrm{CO}_{2}$ storage in the Indian Subcontinent, IEAGHG R\&D Programme Report (2008), Cheltenham).

\section{CCS and Clean Development Mechanism}

CCS deployment in India will need the following steps of the CDM project cycle to be carried out before a sustainable and viable CCS-CDM model is envisioned:

1. Research and Development

2. Project Appraisal

3. Approval \& Validation

4. Implementation, Monitoring \& Verification

5. Carbon Credits issued

6. Cap and Trade System

7. Opportunities

These levels will involve all the stakeholders of the economy, namely the Government, Project Developers, Technology Providers, Financing Body and the CDM experts.

\subsection{Research and Development}

The most significant areas of IP in CCS generally appear to be regarding carbon capture and site selection technology defining a well-defined boundary for the CCS project will be a daunting task, requiring extensive study of the geological formations and dynamics of the region. Services covered the conceptual design, technical and financial modelling, investment appraisal, comparison of options and costs, evaluation of risks and sensitivities.

\subsection{Project Appraisal}

The project appraisal stage of the CCS-CDM project will entail establishing a Baseline and additionally for the CCS technology. For this it will be important to define the project boundaries that will identify the source and sink of the $\mathrm{CO}_{2}$ that has been captured through CCS technology. Since major part of the storage of captured $\mathrm{CO}_{2}$ will be done under bedrocks and aquifers, defining a well-defined boundary for the CCS project will be a daunting task, requiring extensive study of the geological formations and dynamics of the region. Fixing the baseline for CCS-CDM project will be unique for every project, since the point $\mathrm{CO}_{2}$ sources and potential storage locations are rarely at coincidental places, as shown in Fig 4 [12]. The next step in project appraisal is the verification against leakage of $\mathrm{CO}_{2}$ from the storage locations. Since the possibility of $\mathrm{CO}_{2}$ storage in India are located in the on-shore and offshore deep saline formations, basalt formation traps, unmineable coal seams and depleted oil and gas reservoirs; the cost involved in the verification against leakage will be costlier than that in other CDM projects. The Project Appraisal should also consider the permanence of the containment, mainly the possibility of the captured GHGs to be released in the atmosphere in the future. Since the permanence of CCS cannot be established up to $100 \%$, it will become important to establish liabilities in case of premature seepage of the captured $\mathrm{CO}_{2}$. After the contract between the buyer and seller has been signed, mentioning the ownership, intellectual property, responsibility, price and technology transfer; the parties will negotiate the various terms related to the crediting period. Crediting period in case of CCS project can be of a renewable-crediting type with longer crediting time, since the CCS technology has long economic lifetime and once fully implemented will not need significant technological changes for years [16]. There can be long periods during which the CCS projects can be considered additional, that are as a technology that is not business-as-usual investment. The next step in project design is the identification and mitigation of risks involved with the CCS project. The main risks identified are the following:

1. Project Risks: common to conventional projects

2. Political Risks: common to conventional projects

3. CDM Risks: unique to CCS-CDM projects

We will focus mainly on the CDM risks that are unique to such projects. Some of the prominent CDM risks are the non-approval of the CDM Executive board of the CCS technology led CDM projects, pricing of the CERs, technology-risks in this technology intensive CCS project. To mitigate these risks, it is important to start the project as early as possible and with the collaboration of the two main parties of the project; the CDM expert and the CCS technology expert. The volatility of the pricing of CERs can be taken care of by locking in the CER prices with the use of CER Derivatives. Sometimes the price risks involved with the CDM projects lead to discounting of CER prices, that is unfavorable to the CDM developers. The last step in project 
appraisal will be the preparation of a detailed Project Appraisal Document.

\subsection{Approval \& Validation}

The CCS project will need approval of Designated National Authority. This body will ensure that the goals of the project are commensurate with the climate-change mitigation aims of the Government. The DNA will also determine if the CCS project is beneficial for the local community. The project should not be just a technological show-case, but must be a value addition to the existing knowledge of Climate change mitigation. After approval from the DNA, the Project Appraisal document will be sent to the Operational Entity for validation. The OE will verify the following Protocols and Convention:-

1. United Nations Convention on the Law of the Sea (UNCLOS) 1982

2. Convention on the Prevention of Marine Pollution by Dumping of Wastes and other Matter (the London Convention) 1972

3. Convention for the Protection of the Marine Environment of the North East Atlantic (the OSPAR Convention) 1992

4. Kyoto Protocol and the environmental impact of the CCS technology. It will also validate the baseline proposed for the CCS project in the Project Appraisal document.

\subsection{Implementation, Monitoring and Verification}

After registration with the CDM executive committee, the CCS project can be executed. But the implementation of the technology-intensive CCS project can take a longer time than most of the existing CDM projects. The project developers will be require to simultaneously monitor the $\mathrm{CO}_{2}$ emission reductions. This monitoring should be done for the $\mathrm{CO}_{2}$ emitted during and after the implementation of the CCS project. The results of the monitoring should be verified by an independent body. This body will issue certificate stating the amount of $\mathrm{CO}_{2}$ reductions and its ownership.

\subsection{Carbon Credits Issued}

Carbon credits (often called a carbon offset) are certificates issued to countries that have successfully reduced emissions of GHG which causes global warming. Carbon credits (or) certified emission reductions are a certificate just like a stock. This can be used by governments, industry or private individuals to offset damaging carbon emissions that they are generating. Carbon credits create market for reducing greenhouse emissions by giving a monetary value to the cost of polluting the air. Each carbon credit represents one tonne of $\mathrm{CO}_{2}$ either removed from the atmospheres or saved from being emitted. Carbon credits can be created in many ways but there are two broad types.

1. Sequestration (retaining or capturing $\mathrm{CO}_{2}$ from the atmosphere) such as afforestration \& reforestration activities.

2. $\mathrm{CO}_{2}$ saving projects such as the use of renewable energies (wind power, solar energy, biomass power, hydropower.

Carbon credits can be viewed as a means of empowering the market to care for the Environment. carbon credits can be bought and sold in international markets at prevailing market price.

\subsection{Cap and Trade System}

A regulatory system that is meant to reduce certain kinds of emissions and pollution and to provide companies with a profit incentive to reduce their pollution levels faster than their peers. Under a cap-and-trade program, a limit (or "cap") on certain types of emissions or pollutions is set, and companies are permitted to sell (or "trade") the unused portion of their limits to other companies that are struggling to comply. Cap and trade is a policy approach for controlling large amounts of emissions from a group of sources. The approach first sets an overall cap, or maximum amount of emissions per compliance period, for all sources under the program. The cap is chosen in order to achieve a desired environmental effect. Authorizations to emit in the form of emission allowances are then allocated to affected sources, and the total number of allowances cannot exceed the cap. Individual control requirements are not specified for sources; instead, sources report all emissions and then surrender the equivalent number of allowances at the end of the compliance period. Allowance trading enables sources to design their own compliance strategy based on their individual circumstances while still achieving the overall emissions reductions required by the cap. Affected units can tailor their compliance plans to each source. Compliance strategies in well-designed cap and trade programs require no prior approval, allowing sources to respond quickly to market conditions and government regulators to remain focused on results. Sources must also accurately measure and report all emissions in a timely manner to guarantee that the overall cap is achieved.

\subsection{Opportunities}

(i) Opportunities in Oil and Gas operations:-

Capturing the $\mathrm{CO}_{2}$ from the oil refinery and thermal power plants can make us rich of $\mathrm{CO}_{2}$. In industry $\mathrm{CO}_{2}$ can be used productively to enhance oil recovery. This technology is been used from 1970's. So enhance oil recovery can be very big potential business opportunity.

(ii) Opportunities in Power Sector.

The liquid transportation fuels, such as diesel, gasoline, and jet fuel, as the primary culprits in greenhouse gas. In fact, transport fuel contributes $21 \%$ of $\mathrm{CO}_{2}$ emissions globally, a bit less than the $27 \%$ produced by power generation. By 2030 , however, the International Energy Agency predicts that the growth in $\mathrm{CO}_{2}$ emissions from coal-fired power in just three countries - China, India and the US - could outpace the growth in transport emissions worldwide-by $80 \%$. Globally electric power generation accounts for more than a quarter of $\mathrm{CO}_{2}$ emissions. It's clear that we must reduce emissions from every source possible, including transport, reducing $\mathrm{CO}_{2}$ 
emissions from power plants is critical. And CCS, which is best applied at large, stationary emission sources, is the ideal solution for this challenge.

(iii) Opportunities in the Transportation Sector:-

It is impossible to capture $\mathrm{CO}_{2}$ from hundreds of millions of exhaust pipes. The real challenge is to reduce the $\mathrm{CO}_{2}$ intensity of liquid fuels based transport on wells-to- wheels basis. This can be done by mixing in the right biofuels, building lighter-weight vehicles, developing more efficient engines, and in the longer term, adding CCS to liquid hydrocarbon fuel production

(iv) Opportunities for society and for business:-

CCS can help us reduce emissions from our oil and gas operations, manage our business risk, enhance oil recovery, alleviate $\mathrm{CO}_{2}$ pressure on the planet and enable liquid fuels to continue helping to satisfy the world's ravenous appetite for energy. These opportunities are good for society and they're good for business.

\section{Conclusion}

It is necessary for developed countries to demonstrate CCS at commercial scale before any commercial scale CCS projects in India are considered. The need for careful consideration of technology transfer arrangements, including intellectual property rights (IPR), to take account of the needs of multiple stakeholders to find workable solutions in this area. The importance of ensuring that technology transferred in any agreements take account of what options are likely to be suitable to be adapted for local conditions, including careful consideration of the implications of the low quality of typical Indian coals. Both the availability of suitable storage sites and identifying routes for transporting captured $\mathrm{CO}_{2}$ to storage sites require careful consideration.

\section{References}

[1] India Green File, December 1 to 31, 2012 No. 300 published by Centre for Science and Environment, New Delhi- 110062.

[2] Joseph A. Aldy \& R. Stavins, The Promise and Problems of Pricing Carbon: Theory and Experience.Journal of Environment and Development 21(2) 2012: 152-180.

[3] G. Marland, T. Boland and R.J. Andres (2007), National $\mathrm{CO}_{2}$ http://cdiac.ornl.gov/ftp/trends/emissions/ind.dat Emissions from Fossil-Fuel Burning, Cement Manufacture and Gas Flaring: 1751-2004.

[4] http://co2now.org/
[5] Juliette Addison et al, Carbon Sequestration in Climate Change: A Guide to Carbon Law and Practice (Paul Q. Watchman (ed.), London: Globe Business Publishing Ltd, 2008) pp. 287-288.

[6] Olawuyi Damilola Sunday, Enlisting Carbondioxide Capture and Storage as a Clean Development Mechanism Project: Legal and Regulatory Issues Considered 2006, p.11

[7] Singh, A. K., Mendhe, V. A and Garg, A. (2006). " $\mathrm{CO}_{2}$ sequestration potential of geological formations in India". 8th International Con- ference on Greenhouse Gas Control Technologies. Trondheim, Norway.

[8] [IEA, Legal Aspects of Storing $\mathrm{CO}_{2}$ : Updates and Recommendations, 2007 p. 20 available at https://www.iea.org/textbase/nppdf/free/2007/legal_aspects.pd $\mathrm{f}$ (last visited on $18 \mathrm{May}, 2015)$. All new coal fired power plants built in the EU after 2020 are required to include CCS or be capture ready.

[9] Kate Robertson, Jette Findsen, Steve Messner, International Carbon Capture and Storage Projects Overcoming Legal Barriers DOE/NETL-2006/1236, June 23, 2006 in a Communication with Geo-Energy and Geo-Information Division, TNO Norway, June 2006.

[10] Barrow Island Act 2003 (WA) Section 13, available at http://www.austlii.edu.au/au/legis/wa/consol_act/bia2003145/s 13.html (last visited on 18 May, 2015).

[11] IEAGHG, A regional assessment of the potential for $\mathrm{CO}_{2}$ storage in the Indian subcontinent. IEAGHG R\&D Programme Report, IEAGHG R\&D Programme, Cheltenham, 2008.

[12] IEA GHG (2007). $\mathrm{CO}_{2}$ Capture Ready Plants. IEAGHG R\&D Pro- gramme Report 2007/4. Cheltenham, UK, International Energy Agen- cy Greenhouse Gas R\&D Programme.

[13] Singh, A.K., Mendhe, V., Garg, A., 2006, "CO 2 sequestration potential of geological formations in India", 8th International confer- ence on Greenhouse Gas Control Technologies, GHGT-8, Trondheim, Norway, June 19-22, 2006.

[14] P.S. Norman, Evaluation of the Barapukuria coal deposit, NW Bangladesh. In: Case Histories and Methods in Mineral Resource Evaluation (A.E. Annels, ed.). Geological Society Special Publication 63, 107-120.

[15] A. Mondal, Gondwana Basins in India - Vast Geologic Storage Sites for $\mathrm{CO}_{2}$ injection. Proceedings of the International Workshop on $\mathrm{R} \& \mathrm{D}$ Challenges in Carbon Capture and Storage Technology for Sustainable Energy Future, January 12-13 2007, National Geophysical Research Institute, Hyderabad, India.

[16] Robert N. Stavins, "Experience with Market-Based Environmental Policy Instruments." In Handbook of Environmental Economics, vol. I, ed. Karl-Göran Mäler and Jeffrey Vincent, 355-435. Amsterdam: Elsevier Science. 2003. 